\title{
Recent Changes in the Spanish Rail Model: the Role of Competition
}

\author{
JAVIER CAMPOS * \\ University of Las Palmas, Spain
}

\begin{abstract}
After a brief historical overview of its main achievements, this paper examines some of the most relevant characteristics of the Spanish rail system and its performance in recent years. It particularly focuses on the new organizational model emerging from the 2003 Railroad Law which, after January 2005, introduced vertical separation and competition in the traditional monopolistic structure of this sector. Although it is early to fully evaluate the results of this change, some interesting lessons can be learnt for countries following the same model.
\end{abstract}

\section{Introduction}

The inauguration in 1848 of the first railroad service in mainland Spain ${ }^{1}$ was widely heralded as a "clear means of progress, aimed at bringing prosperity to industrialists and peasants alike, by shortening the travel distances among the cities and the regions". Supporters hoped that the railroad would accelerate Spain's delayed industrialization and become the instrument some day in the future, for uniting a country with a beautiful but difficult topography.

Once the initial network design was completed and the basic infrastructure deployed (mostly, by foreign private capital), after WWII, Spain adopted the same "rail model" of its European neighbors. This model was characterized by the existence of a vertically integrated government-owned monopoly, whose management relied upon social objectives, rather than on commercial ones. RENFE (Red Nacional de Ferrocarriles) was born in 1941 to rescue the existing private operators from the ashes of the Spanish Civil War (1936-1939) and remained the uncontested provider of rail services for over 60 years.

As in many other European countries, the model was progressively reformed during the second half of the twentieth century. Rail dominated transport in Spain until the 1960s, when competition from other modes started to sharply erode its position. Figure 1 shows that about 60 percent of domestic passengers and 35 percent of freight traveled by train in

\footnotetext{
* Contact Author. Department of Applied Economics, University of Las Palmas, Campus de Tafira, E35017, Las Palmas, Canary Islands, Spain. E-mail: jcampos@daea.ulpgc.es Financial support from the Spanish Ministry of Science and Education and from FEDER through grant SEJ2004-00143 is gratefully acknowledged.

${ }^{1}$ This railroad connected the industrial cities of Barcelona and Mataró (28 kilometres). However, the first Spanish railroad was actually built in Cuba (then, a rich overseas province) in 1837, with more than 90 kilometres of track. For a detailed review of the history of the rail industry in Spain, see Comín et al (1998).
} 
1950. However, by 2002 rail's share had declined to 5.1 percent of passengers and 3.1 percent for freight. Although rail passenger traffic continued to grow in absolute terms, other modes grew even faster. After 1980, rail freight traffic failed to grow much even in absolute terms.

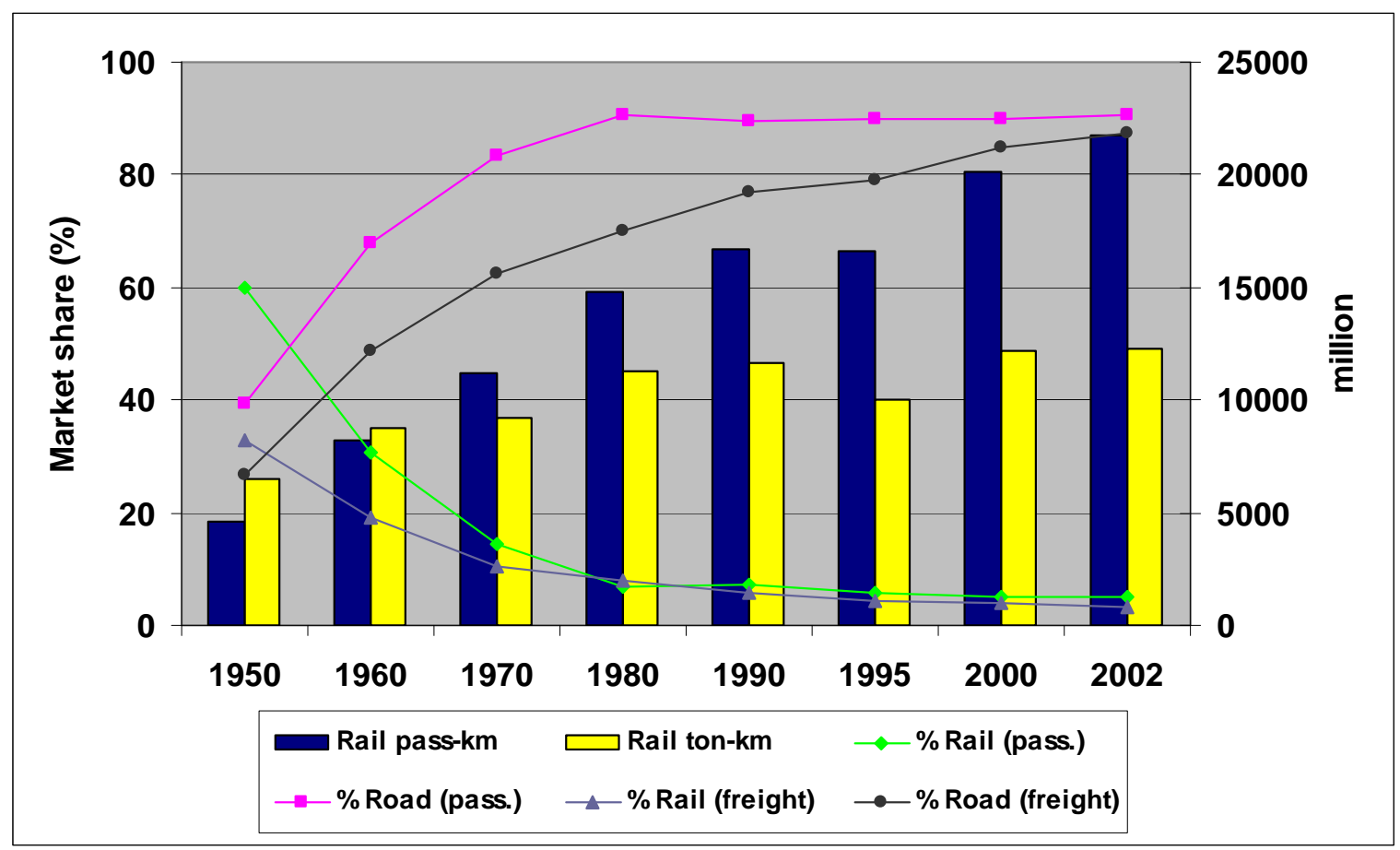

Figure 1: The decline of railways vs. the roads: market share and growth

Source: INE (National Institute for Statistics, $\underline{\text { www.ine.es)}}$.

These traffic trends are common to other countries with the same rail model. They can be explained not only by the development of alternative modes of transport but also by the inability of the railways to adapt to the evolving economic conditions (Campos and Cantos, 2000). For this reason, since the early 1990s, the European Union has pursued an active reform of its rail policy. As in other industries, the change has been aimed at modernizing the sector through the introduction of competition, so as to guarantee the future of the industry by stopping its steady loss of market share and the growing financial deficits of national operators.

As we will see, Spain was first reluctant to radically change its approach and chose instead incremental reforms with little, mostly nominal, changes in its rail model. However, RENFE's performance during the 1990s finally convinced the government that a more radical reform - getting rid of the monopoly and opening the tracks to real competition - was needed. This has been finally accepted in the 2003 Rail Sector Law, which went into effect in January 2005. 


\section{A brief history}

The early development of the rail industry in Spain was strongly affected by the political turmoil and the uneven economic growth that the country experienced between 1850 and 1940. The benefits of the industrial revolution arrived late and were mostly concentrated in a few areas of the Basque Country, Catalonia and Madrid. The rest of the country remained rural, poor and isolated from the main cities.

In this context, railroads were regarded as an integrating infrastructure and were soon declared a "public service of national interest" (1855 General Railroad Law). However, lacking enough public funding and political support to develop the new industry, the law relied on promising financial incentives to foreign investors. As a result, large amounts of capital were attracted into the country and French-owned private companies, such as MZA (Madrid-Zaragoza-Alicante) and Perèire, dominated the sector initially.

The infrastructure expanded at a very fast pace. By 1860, there were almost 500 kilometers of tracks and more than 25 stations. By 1870, the sector had become an attractive business opportunity for local entrepreneurs, as well as foreigners, and government passed a new railways law that encouraged the award of a large number of concessions to build new infrastructure and operate freight and passenger services. In 1877 (after a new government, and yet another new rail law), railway companies extended their networks to other corridors in the north and east of the country, and just before 1900, the figure of 10,000 kilometers of tracks had been reached. By this time, many European railroads had also developed international services that crossed national borders. For political and geographical reasons, however, most of the Spanish network had been built with the so-called Iberian gauge (1.666 meters), instead of the standard European gauge (1.435 meters). This isolated the markets from France (trains had to be switched) and limited further expansion possibilities.

\subsection{The birth of RENFE}

The financial performance of many rail companies started to deteriorate after World War I. The increase in coal prices and the social and political turbulence that later grew into the civil war reduced traffic. In 1939, just when the companies were on the brink of extinction and the infrastructure was severely damaged, the new government decided to rescue the industry by radically changing its rail model. RENFE was born in 1941 to absorb most of the existing private companies into a centralized and vertically integrated body, directly controlled by the Ministry of Transport. A few companies that operated narrow gauge services, mostly in industrial regions of the north, remained in private hands until 1965 when they were absorbed into another state-owned railway company, FEVE.

A new legal framework passed in 1947 explicitly defined the railways as the country's main transport mode, with road being given a secondary role. The monopolistic nature of RENFE, the only long-distance operator, was reinforced by a legal barrier to entry which severely restricted intermodal competition, both in passenger and freight markets, and especially in those corridors already served by the railways. The government also imposed a special tax on truckers (aptly named the canon de coincidencia), which increased with truck size and was used to finance the railways.

These policies did not prevent the spectacular growth of road traffic during the 1950s and 1960s (see Figure 1), since highway modes were often cheaper, more flexible and more convenient for many users. Until 1971, it was relatively easy to get the permissions 
needed to establish a small trucking company, and the sector grew exponentially largely through small (driver-owned) companies. Restrictions on trucking were tightened significantly in 1971, with the support of both the trucking associations and the railways, who argued that there was too much "wasteful competition”, because trucking was plagued with low demand and excess capacity. The legislation passed restricted entry in road freight markets, distorting the operators' choice of truck size and the optimal dimension of the industry. It was not sufficient though, to reverse the decline of the rail sector, which soon spread to passenger markets with the rapid growth of private car ownership beginning in the 1970 s. $^{2}$

\subsection{The reforms of the $1980 \mathrm{~s}$}

It was not until 1984 when a new effort to change the situation of the Spanish railways was made. The government and RENFE signed their first management contract (Primer Contrato-Programa: 1984-1986) with the aim of stopping the financial decline of the company by improving its quality, reducing overmanning and closing down some unprofitable lines. The contract was the first attempt ever to deal with the excess capacity and inefficiency problems of the sector and its results were promising: 6.4 per cent of the total network was closed down, the workforce was reduced by 28 percent and productivity rose substantially in just two years. Demand remained constant during this period, even though fares were increased with the retail price index (except in 1986, the year which saw the introduction of VAT, when fares grew twice as much as the price index). The company's financial position did not improve as much as hoped, however, so the government decided that new measures had to be implemented.

Another round of reform was introduced in 1987 through the Surface Transport Law (Ley de Ordenación del Transporte Terrestre, or LOTT). The LOTT revoked the modal preference for rail transport and instead promoted competition among all modes. For the first time in 40 years, private investors were allowed to build and operate new rail lines (although none did). RENFE was transformed into an autonomous public company, among whose new explicit objectives were the achievement of financial balance.

The LOTT was accompanied by the Rail Transport Plan (Plan de Transporte Ferroviario, or PTF), which defined new guidelines for railway transport policy. That same year a second management contract was also signed (Segundo Contrato-Programa: 1988-1991), this time including a more specific investment plan, new financing mechanisms, policies for pricing and service levels, and a novel public control system designed to evaluate the results of the PTF's based on an ex-post analysis of performance indicators and a detailed auditing of the investments projects.

Although the policy guidelines of the PTF were not fully implemented at the time, they anticipated many of the principles of the European rail policy in the 1990s. Among others, the guidelines recommended that:

(1) Rail infrastructure and services should be responsive to demand, with the introduction of new technologies to improve quality and competitiveness whenever possible,

(2) Rail planning and management should be based upon economic targets, introducing financial constraints when necessary, and pursuing, as the ultimate goal, the efficient allocation of resources,

\footnotetext{
${ }^{2}$ See Carbajo and de Rus (1991) for a detailed analysis of transport policy in Spain during the 1980s.
} 
(3) Rail services should operate in competition with other transport modes, some of which (such as air transport) were also beginning to be deregulated. In general, prices should cover costs in passenger as well as freight services. If prices were set below costs because of public service obligations (PSO), the company should be compensated.

In 1989, again anticipating some of the changes that other railways would make later, RENFE was reorganized into decentralized management units (Unidades de Gestión Descentralizada, or UGD) based upon lines of business rather than geographic territory. The UGDs were grouped into three categories: transport operators (both passenger and freight), service suppliers (such as rolling stock maintenance) and infrastructure (both maintenance and operations). The objective was to induce more commercial behavior since each UGD would operate independently, using transfer prices to charge for services rendered to other UGDs. The hope was that the commercial incentives would encourage efficiency and reduce the need for financial support from the government.

The third management contract (Tercer Contrato-Programa: 1994-1998) was specifically designed to support this new strategy by defining detailed financial objectives to be achieved by each UGD. Within the transport operators, the business units for regional services and suburban commuter services were awarded the condition of "public service", thus deserving subsidies to compensate their deficits. Suburban commuter services were granted a subsidy per passenger-kilometers to reflect the reductions of traffic congestion and pollution they achieved. Regional services got a lump sum transfer to compensate unexpected losses.

\subsection{The consequences of the EC Directive 1991/440}

In 1991, the European Commission called for fundamental railway reforms based on the experiences of a number of countries (notably Sweden and New Zealand) that had already reformed their industries during the 1980s. The cornerstone of the reform was in EC Directive 1991/440, which set out the objective of unbundling infrastructure from operations by either full separation or, at least, the creation of different organizations and accounts within one holding company in order to increase transparency and make competition easier. Other objectives of the directive were "to create independent regulatory institutions for railways", "to devise a system of infrastructure charges' and 'to open access to national railway markets for competitors". ${ }^{3}$

Spain responded to the EC directive in 1994, by transforming RENFE's UGDs into proper business units with separate accounts and objectives. Rail services were divided into six major business units: long distance, regional, suburban, AVE (Spanish short for alta velocidad, or high speed), general freight and intermodal containers. Infrastructure and rolling stock activities were also grouped into several specialized business units, including stations, maintenance, repairs, signaling and computing services. The 1994 statute also increased the internal autonomy of the business units and the nominal independence of the company from the government. RENFE was allowed commercial freedom in setting fares,

\footnotetext{
${ }^{3}$ In 2001, a new rail package clarified the principles on which rail infrastructure management should be based on and, very recently, through EC Directive 2004/51, the deadlines for implementing "third party access" have been shortened (to January 2007). However, many of these changes were not implemented in Spain until the 2003 Rail Sector Law (see below).
} 
for example, although price increases had to be approved by the Ministry of Transport (later, the Ministry of Development).

In 1997, responding again to EC Directive 91/440, the government created the Rail Infrastructure Manager (Gestor de Infrastructuras Ferroviarias, GIF), a public body in charge of building and maintaining all new rail infrastructure. The GIF was also responsible for managing the existing infrastructure (tracks, stations, depots and land nearby) and the signaling systems. Its services were financed through track access fees paid by the rail operators, allowing a formal accounting separation of the GIF and RENFE balance sheets in compliance with EC regulations.

A final contrato-programa was put in place between 1999 and 2000, designed to consolidate the unbundling model while simultaneously providing RENFE with enough funding to finance the acquisition of the expensive rolling stock for the AVE business unit. The contract was not renewed, however, because company managers and government officials generally agreed that "regulation by management contract system" had achieved all it could. Additional changes would wait for the passage of a new sector law, a step finally taken in 2003.

\section{Evaluating the reforms}

Over two decades, RENFE had gradually evolved from a centralized and vertically integrated government agency into a firm which, although still state-owned, had been decentralized into business units operating with commercial criteria. Table 1 shows that the company has made a considerable effort in reducing capacity since 1980 by closing unprofitable lines and reducing excess staff. Between 1980 and 2002, RENFE more than halved its staff and closed down above 2,000 kilometers of lines, some of which were transferred to regional governments or to small private companies operating specialized freight services or tourist routes. At the same time, huge amounts of capital were invested in the high speed passenger services and the rolling stock was modernized through the acquisition of new locomotives and passenger cars. ${ }^{4}$

\begin{tabular}{|l|l|l|l|l|l|l|}
\hline & $\mathbf{1 9 8 0}$ & $\mathbf{1 9 8 5}$ & $\mathbf{1 9 9 0}$ & $\mathbf{1 9 9 5}$ & $\mathbf{2 0 0 0}$ & $\mathbf{2 0 0 2}$ \\
\hline Network length $(\mathrm{km})$ & 15724 & 14804 & 14539 & 14291 & 14251 & 13970 \\
\hline Locomotives & 1860 & 2108 & 2072 & 2096 & 1693 & 1664 \\
\hline $\begin{array}{l}\text { Wagons and freight } \\
\text { cars }\end{array}$ & 41007 & 42032 & 37235 & 27863 & 28397 & 26931 \\
\hline Employees & 72931 & 74957 & 55551 & 44277 & 32584 & 31422 \\
\hline
\end{tabular}

Table 1: Evolution of RENFE's infrastructure and fleet

Source: RENFE (www.renfe.es).

RENFE continues to dominate the provision of rail services in Spain despite the possibility, first opened by the LOTT in 1987, of new entry into the rail business. In 2002,

\footnotetext{
${ }^{4}$ As of January 2005, with the completion of some of the new high speed lines, RENFE operated over 13,500 kilometres of track, although less than 10 percent of the network was European gauge and only 16 percent was double-track and electrified.
} 
it enjoyed a market share of 92 percent of the total of passenger-kilometers that traveled by train that year with four regional public companies accounting for 7 percent, ${ }^{5}$ while the remaining share mostly corresponded to FEVE. In freight, RENFE maintained a share of 95 percent of total ton-kilometers, with FEVE holding a stable 4 percent over the same period. This unchallenged position was reflected in the company's operating and financial performance.

\subsection{Operating performance}

Between 1990 and 2003, RENFE's passenger traffic increased at an average annual rate of 1.8 percent, while freight grew at an average rate of 1 percent, as shown in Table 2. In contrast, Spain's GDP and population grew by 7 and 5 percent per year during the same period.

\begin{tabular}{|l|l|l|l|l|l|l|l|}
\hline & $\mathbf{1 9 9 0}$ & $\mathbf{1 9 9 5}$ & $\mathbf{2 0 0 0}$ & $\mathbf{2 0 0 1}$ & $\mathbf{2 0 0 2}$ & $\mathbf{2 0 0 3}$ & $\begin{array}{l}\text { \% } \\
\text { average } \\
\text { change }\end{array}$ \\
\hline Long distance & 8.455 & 8.405 & 7.033 & 6.986 & 6.949 & 6.627 & $-1.48 \%$ \\
\hline Suburban & 4.595 & 6.132 & 7.114 & 7.556 & 7.775 & 8.031 & $3.53 \%$ \\
\hline Regional & 2.426 & 2.074 & 2.482 & 2.572 & 2.575 & 2.624 & $2.12 \%$ \\
\hline AVE & -- & 1.294 & 1.942 & 2.077 & 2.181 & 2.027 & $2.69 \%$ \\
\hline $\begin{array}{l}\text { Total passenger } \\
\text { traffic }\end{array}$ & $\mathbf{1 5 . 4 7 6}$ & $\mathbf{1 7 . 9 0 5}$ & $\mathbf{1 8 . 5 7 1}$ & $\mathbf{1 9 . 1 9 1}$ & $\mathbf{1 9 . 4 8 0}$ & $\mathbf{1 9 . 3 0 9}$ & $\mathbf{1 . 7 9 \%}$ \\
\hline General cargo & 7.745 & 6.709 & 7.260 & 7.397 & 7.369 & 7.392 & $-0.02 \%$ \\
\hline Combined transport & 2.473 & 3.095 & 4.360 & 4.352 & 4.291 & 4.473 & $5.05 \%$ \\
\hline Total freight traffic & $\mathbf{1 0 . 2 1 8}$ & $\mathbf{9 . 8 0 4}$ & $\mathbf{1 1 . 6 2 0}$ & $\mathbf{1 1 . 7 4 9}$ & $\mathbf{1 1 . 6 6 0}$ & $\mathbf{1 1 . 8 6 5}$ & $\mathbf{1 . 0 1 \%}$ \\
\hline
\end{tabular}

Table 2: RENFE's traffic evolution by business units (1990-2003)

Source: RENFE (www.renfe.es). Data represent billions of passenger-kilometers and ton-kilometers.

The aggregate traffic trends hide differences among business units. Among passenger services, the AVE and the suburban and regional services experienced notable increases in traffic thanks partly to increases in quality, growing urban highway congestion and the introduction of specialized services such as the Talgo and Intercity trains). Traditional (non-high speed) long-distance services, by contrast, have lost much of their appeal among customers, who now prefer air travel for distances between 300 to 400 kilometers. This shift to faster passenger services is common to countries with growing per capita incomes and is mostly unrelated to the economic competitiveness of the railroad. Among freight service, intermodal containers have grown rapidly since 1965 but general cargo has stagnated in the face of aggressive competition by trucks and the inability of rail services to match the flexibility or, in some cases, the geographic coverage of its highway competitor. $^{6}$

\footnotetext{
${ }^{5}$ These small companies (Ferrocarrils de la Generalitat de Catalunya, Ferrocarrils de la Generalitat Valenciana, Euskotren and Serveis Ferroviaris de Mallorca) are public local monopolies controlled by the regional governments. They provide suburban and regional services without competing with RENFE.

${ }^{6}$ Due to the coastal nature of the country and the important traffic with the Balearic and Canary Islands, freight maritime transport is also very relevant in Spain. In 2003, it enjoyed a 10 percent market share.
} 
Table 3 shows trends in productivity and quality of services in RENFE's business units. The load factor measures the extent to which supply has adapted to demand. Passenger load factors have remained relatively low (around 35 percent) in both suburban and regional services, which are affected by public service obligations. For these business units, the government sets (and compensate the company for) the minimum level of service to be provided according to social criteria, which yields a generalized excess capacity. But load factors have remained high in long-distance services (where RENFE has reduced capacity in recent years) and in the AVE high speed business, which is the most profitable and attractive of RENFE's operating units. Neither of these is subject to PSO compensations. The load factors for the two freight business units have remained low, suggesting chronic excess capacity.

\begin{tabular}{|l|l|l|l|l|l|l|}
\hline & $\mathbf{1 9 9 0}$ & $\mathbf{1 9 9 5}$ & $\mathbf{2 0 0 0}$ & $\mathbf{2 0 0 1}$ & $\mathbf{2 0 0 2}$ & $\mathbf{2 0 0 3}$ \\
\hline Long distance & & & & & & \\
\hline Load factor (\%) & - & 65.5 & 67.6 & 68.8 & 69.6 & 66.8 \\
\hline Pass-km per employee ('000) & 2976.1 & 3006.7 & 3060.5 & 3357.0 & 3511.4 & 3458.8 \\
\hline \% Punctuality (<10 min.) & - & - & 95.5 & 95.7 & 94.8 & 90.4 \\
\hline Suburban services & & & & & & \\
\hline Load factor (\%) & - & 35.1 & 37.4 & 37.3 & 37.3 & 37.8 \\
\hline Pass-km per employee ('000) & 1567.3 & 1773.7 & 1836.3 & 1897.5 & 1983.9 & 2012.8 \\
\hline \% Punctuality (<10 min.) & - & - & 99.1 & 98.9 & 98.8 & 98.4 \\
\hline Regional services & & & & & & \\
\hline Load factor (\%) & - & 33.7 & 35.6 & 35.9 & 35.5 & 35.3 \\
\hline Pass-km per employee ('000) & 1345.8 & 1658.7 & 1733.2 & 1755.6 & 1696.3 & 1649.3 \\
\hline \% Punctuality (<10 min.) & - & - & 96.9 & 96.8 & 96.8 & 94.8 \\
\hline High speed (AVE) & & & & & & \\
\hline Load factor (\%) & - & - & 64.0 & 64.1 & 66.2 & 63.5 \\
\hline Pass-km per employee ('000) & - & 7618.5 & 7139.7 & 7471.2 & 6990.4 & 5774.9 \\
\hline \% Punctuality (<10 min.) & - & - & 98.5 & 98.2 & 99.9 & 99.9 \\
\hline General cargo & & & & & & \\
\hline Load factor (\%) & - & 35.2 & 35.8 & 36.3 & 36.7 & 37.0 \\
\hline Ton-km per employee ('000) & 987.0 & 1457.9 & 1915.6 & 1813.9 & 1905.6 & 2018.0 \\
\hline Combined transport & & & & & & \\
\hline Load factor (\%) & - & 46.2 & 41.4 & 40.8 & 40.3 & 40.9 \\
\hline Ton-km per employee ('000) & 1250.7 & 1550.5 & 2658.5 & 2462.9 & 2531.6 & 2822.1 \\
\hline
\end{tabular}

Table 3: RENFE's performance by business unit (1990-2003)

Source: RENFE (www.renfe.es) and UIC estimates (www.uic.asso.fr) for 1990.

RENFE's record on labor productivity is also mixed, as shown in Table 3. In the last five years, the number of passenger-kilometers per employee has increased by 15 percent in long distance service (mostly due to staff reductions) and by 13 percent in suburban services (due to traffic increases). Labor productivity has stagnated in the remaining 
passenger business units but has almost tripled in freight largely because of staff reductions rather than output increases. ${ }^{7}$

The primary measure of service quality reported by RENFE is the percentage of trains departing and arriving within 10 minutes of the scheduled timetable. By this measure, RENFE performs very well, with over 95 percent of passenger services on time. Performance is even better in the case of AVE, due to a highly advertised "punctuality commitment”, used by the company to successfully attract time-conscious customers and steal market share from the airlines.

\subsection{Overall financial performance}

One of the primary goals of the three management contracts signed between RENFE and the government during the 1980s and 1990s was to clarify and make it more transparent the financing of the different rail activities. Both EC Directive 1991/440 and Spain's 1994 railway law also require a clear reporting of the company's finances, including not only the subsidies received for public service obligations but the operating deficit when commercial revenues are insufficient to cover operating costs.

\begin{tabular}{|l|l|l|l|l|l|l|l|l|}
\hline & $\mathbf{1 9 8 0}$ & $\mathbf{1 9 8 5}$ & $\mathbf{1 9 9 0}$ & $\mathbf{1 9 9 5}$ & $\mathbf{2 0 0 0}$ & $\mathbf{2 0 0 1}$ & $\mathbf{2 0 0 2}$ & $\mathbf{2 0 0 3}$ \\
\hline Revenues & 5541.3 & 4100.9 & 3543.3 & 3442.4 & 3024.4 & 3084.6 & 3025.8 & 3019.1 \\
\hline Commercial & 1900.2 & 1851.4 & 1750.5 & 1567.8 & 1730.0 & 1810.3 & 1793.2 & 1700.7 \\
\hline $\begin{array}{l}\text { PSO } \\
\text { subsidies }\end{array}$ & 3641.1 & 2249.5 & 1792.8 & 1874.6 & 1294.2 & 1274.2 & 1232.6 & 1318.4 \\
\hline Costs & 7537.4 & 4767.8 & 3781.4 & 3937.0 & 3187.0 & 3199.2 & 3121.8 & 3003.3 \\
\hline Labor & 2562.6 & 2042.9 & 1643.2 & 1302.9 & 1170.5 & 1178.3 & 1139.2 & 1178.6 \\
\hline Energy & 376.7 & 303.8 & 254.1 & 191.0 & 162.7 & 164.4 & 157.9 & 158.8 \\
\hline Other inputs & 1582.8 & 1151.6 & 845.3 & 812.7 & 751.0 & 787.9 & 844.7 & 816.7 \\
\hline Depreciation & 1206.1 & 339.5 & 413.6 & 604.6 & 559.7 & 541.1 & 541.2 & 480.3 \\
\hline Interests & 1733.6 & 930.5 & 625.3 & 941.6 & 475.7 & 459.6 & 375.8 & 289.1 \\
\hline Other costs & 75.2 & -- & -- & 84.3 & 67.7 & 67.9 & 63.0 & 79.8 \\
\hline Extra profits & -- & -- & 74.2 & -38.0 & -34.4 & -30.9 & -8.7 & 20.9 \\
\hline Net results & - & & & & & & & \\
\hline $\begin{array}{l}\text { Financing } \\
\text { needs (1) }\end{array}$ & - & - & - & - & - & - & - & - \\
\hline
\end{tabular}

Table 4: RENFE's aggregate financial results (1980-2003)

Note: (1) Total government contribution is the sum of subsidies and net results Source: RENFE (www.renfe.es). All figures are expressed in $2003 €$ millions.

Table 4 shows that RENFE's aggregate financial performance improved substantially from 1980 to 2003. Commercial revenues have never covered costs but the sum of the PSO subsidies and the operating deficit has fallen from 5.6 billion euros in 1980 to 1.3 billion euros in 2003 (measured in constant 2003 euros). In 1980 commercial revenues

\footnotetext{
${ }^{7}$ These figures represent a major advance in terms of productivity when compared to other European counterparts, as pointed out in Cantos et al (1999). In general, the company's operating performance improved in comparison to the average of the European railways.
} 
represented only 34 percent of total revenues, whereas in 2003 the figure had reached 56 percent.

The improvement is due in large part to considerable efforts to implement costreducing strategies such as adjusting capacity to demand whenever possible and reducing staff through incentives for early retirement. Operating costs have been cut substantially in real terms, although the rigid cost structure of the company (where labor's share of costs has remained at 40 percent since 1980) makes it difficult to achieve larger cost savings in the near future.

Although RENFE's performance has improved, the figures in Table 4 exaggerate the gains in two respects. First, the company's debt is backed by the Spanish government so that the commercial risk of the company is effectively assumed by the Spanish taxpayer rather than by the buyers of RENFE bonds. This artificially reduces RENFE's cost of capital, which in turn may also distort the evaluation of future investments. Second, RENFE's financial statements do not include the costs of some new rail infrastructure projects built by the government. Dogson and Rodriguez (1996), who first identified this problem, argue that the amount of infrastructure provided by and for the company is thus understated in the balance sheets so that larger cost-reducing efforts may be necessary. The problem was partially solved in 1997, when the accounting separation between infrastructure and services demanded by EC Directive 1991/440 was finally implemented. But the financial costs in Table 4 are strikingly low, as interest payments have been reduced to just 10 percent of total cost in recent years. ${ }^{8}$

\subsection{Financial performance by business units}

Financial performance has varied by business unit, as illustrated in Figure 2, which shows the trend in cost recovery ratios (percentage of operating cost recovered by commercial revenues and PSO subsidies) by business unit from 1997 to 2003. All the business units except regional passenger services and intermodal containers improved their results within this period, although only the AVE consistently maintained cost recovery ratios above 100 percent. AVE's good performance is misleading, since RENFE's accounts do not include much of AVE's infrastructure costs, which may account for up to 70 percent of total costs. In fact, according to De Rus and Inglada (1997), the first AVE line (between Madrid and Seville) hardly recovers operating costs once the infrastructure costs have been correctly accounted for.

The poor financial performance of some of RENFE's business units is troubling since EC regulations and the likely increase in competition will make it more difficult for one business unit, such as the AVE, to cross subsidize others in the future. Moreover, it is important to note that the lowest cost recovery ratios are those that already receive the largest PSO subsidies, particularly the suburban and regional business units. Although PSO subsidies are allowed under current European rail policy, it is likely that governments will be pressed to review them periodically. Recent EU policy documents, such as the 2001 white paper on the future of transport policy, encourage the development of railways because of the external social costs of road transport, but they also call for

“...a periodical review of public support mechanisms that could distort the competition within the

European market” (European Commission, 2001).

\footnotetext{
${ }^{8}$ In comparable private companies, this figure could reach up to $30 \%$, according to the International Railways Association, UIC (see detailed statistics in www.uic.asso.fr).
} 


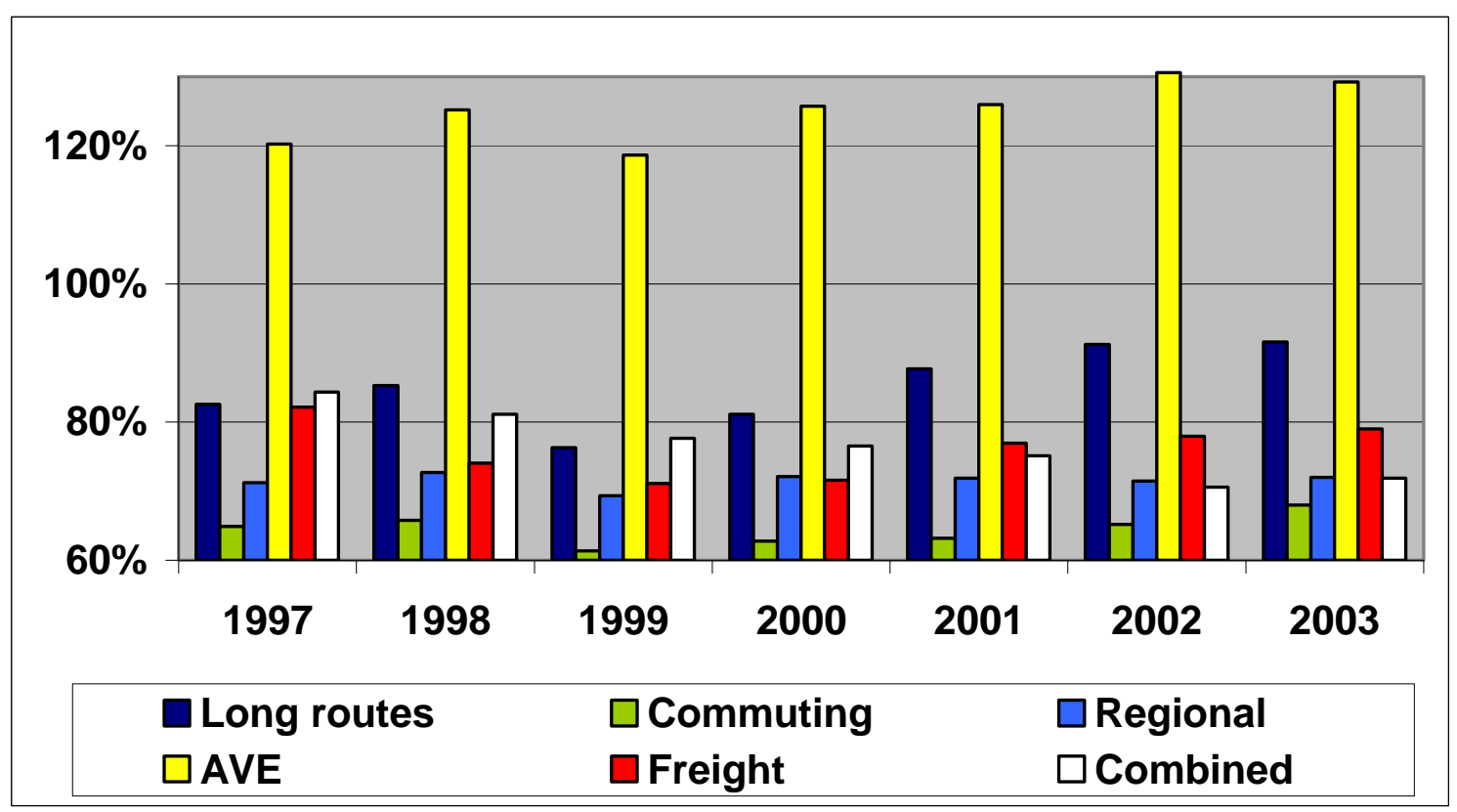

Figure 2: RENFE's cost recovery ratios by business units (1997-2003)

Source: RENFE (www.renfe.es)

\section{Investment trends and the expansion of the AVE}

One of the most important developments in Spanish railway policy has been the decision to invest heavily in rail infrastructure, as shown in Table 5. Between 1980 and 2003, the government investment more than $€ 20$ billion in railways, a sum which allowed the extensive modernization of tracks, stations, signaling systems and rolling stock. Until the late 1990s, RENFE was the major investor in infrastructure and particularly in the maintenance and renewal of existing lines, while the government (through the Dirección General de Ferrocarriles, DGF, the rail department of the Ministry of Development) was in charge of building a few new lines, junctions and by-passes around the most congested areas. FEVE and the regional operators did not open new lines but invested in modernizing their fleets, the development of new services and improved technology.

When the Rail Infrastructure Manager (GIF) was established in 1997, it assumed the responsibility of building the largest expansion of the Spanish rail system in the last fifty years. The government, through a combination of the DGF and the GIF, has invested almost $€ 12$ billion in just four years and has promised a similar amount for the coming decade. The investment in rail is part of the so-called Infrastructure Plan 2000-2007, whose goal is to modernize the country's transport services and infrastructure to achieve the interoperable and open international corridors advocated by European Union transport policy. 


\begin{tabular}{|l|l|l|l|l|l|l|l|l|}
\hline & $\mathbf{1 9 8 0}$ & $\mathbf{1 9 8 5}$ & $\mathbf{1 9 9 0}$ & $\mathbf{1 9 9 5}$ & $\mathbf{2 0 0 0}$ & $\mathbf{2 0 0 1}$ & $\mathbf{2 0 0 2}$ & $\mathbf{2 0 0 3}$ \\
\hline Government & 260.1 & 459.9 & 783.3 & 507.3 & 400.0 & 438.3 & 496.1 & 534.7 \\
\hline GIF & & & & & 1047.2 & 1535.0 & 2484.5 & 2140.8 \\
\hline RENFE & 1180.1 & 630.9 & 1542.4 & 575.4 & 573.6 & 624.4 & 632.8 & 925.2 \\
\hline Rolling stock & 279.2 & 356.2 & 647.9 & 307.6 & 184.6 & 222.2 & 189.6 & 608.9 \\
\hline Infrastructure & 900.9 & 274.7 & 894.5 & 267.8 & 389.0 & 402.2 & 443.1 & 316.3 \\
\hline FEVE & 97.1 & 77.2 & 75.2 & 40.0 & 74.9 & 74.5 & 69.2 & 71.3 \\
\hline $\begin{array}{l}\text { Regional } \\
\text { railroads }\end{array}$ & & 121.3 & 93.2 & 140.6 & 119.1 & 220.3 & 213.9 & 272.5 \\
\hline Total & 1536.9 & 1289.1 & 2494.0 & 1263.3 & 2214.8 & 2892.4 & 3887.4 & 4168.6 \\
\hline
\end{tabular}

Table 5: Total public investment in railroads $(1980-2003)$

Source: Ministry of Development (www.mfom.es). All figures are in 2003 euro millions.

As in the old management contracts of the 1980s, the Infrastructure Plan includes the broad priority "to increase rail transport's market share and improve the financial performance of the operators". ${ }^{9}$ Unlike the old contracts, however, the plan also includes a long list of specific targets, such as reducing the travel time by rail between Madrid and Barcelona and all the major provincial cities. The plan attaches particular importance to the development of the high speed lines, inspired in large part by the example of the French TGV. The government and AVE supporters argue that the environmental damage caused by motor vehicle air pollution and the increasing levels of congestion in both surface and air travel make the railways the preferred transport mode in corridors with enough traffic to justify the substantial investment required by modern railway technology. AVE proponents also hope that shorter time connections between Madrid and the main cities will promote the kind of national integration anticipated from railways as far back as 1848. The European Union has been keen on the creation of a continent-wide high-speed rail network and has committed its financial support for several projects in member countries (European Commission, 2001).

The first AVE service was opened between Madrid and Seville (585 kilometers) in 1992 in conjunction with the international exposition celebrated that year at Seville. The line is widely regarded as a success in terms of passenger acceptance, load factors and quality of service, although ex-post studies show that it drew most of its traffic from modes with already established and costly infrastructure, and that many of its costs were grossly understated. From the point of view of social cost-benefit analysis, it was a doubtful investment (De Rus and Inglada, 1997). ${ }^{10}$

The planned expansion of high speed corridors in Spain will continue in the near future. The AVE line between Madrid and the northeast city of Lleida (465 kilometers) opened for service in 2003 but with the speed temporarily restricted to 200 kilometers per

\footnotetext{
${ }^{9}$ It was also hoped that new rolling stock would contribute to reduce maintenance costs.

${ }^{10}$ It has been widely reckoned that the high speed expansion in Spain has not been based in purely economic criteria. For example, it is interesting to note that the first contrato-programa (1986-1988) ruled out the highspeed alternative because "its financial viability is uncertain, at least as a general option”. However, when the financial support from the European Union was secured this criterion was changed, despite demand and technologies had not.
} 
hour for technical reasons. The line should reach Barcelona in December 2007 and the French border by 2009. Other routes in the north and centre of the country are either under construction or planning.

From an economic perspective, Spain's plan for an extensive network of AVE services is risky. The cost of building the required infrastructure is huge and once built, infrastructure maintenance costs will be high. Demand projections suggest that passenger revenues are unlikely to recover even operating costs. With the EU enlargement towards Central and Eastern Europe and the eligibility of poorer countries to structural and regional funds, Spain is unlikely to enjoy continued generous EU funding for its infrastructure projects. Some observers fear that the displacement of the European centre of gravity eastwards will accentuate the peripheral location of Spain, giving increased importance to the necessary passage through French territory with which connections are to be improved. The AVE remains popular as many regional governments have been lobbying for "their own AVE" in the belief that the original line was an important stimulus to the economy of Seville. Nevertheless, it may be time to reconsider some of the planned investments. ${ }^{11}$

\section{The 2003 railroad law: Will it be enough?}

In 2003, the Spanish government passed a new railroad sector law, the Ley del Sector Ferroviario (LSF), "in order to finally transpose to national legislation the new European directives and establish the basis for the introduction of private competition in the sector". The law assumes that opening the rail sector to private initiative will improve its economic efficiency and increase its share of passenger and freight, and represents the final step of the reforms begun in 1987 with the LOTT. After years of minor adjustments to RENFE's internal organization and management criteria, the LSF introduced three more fundamental reforms. $^{12}$

\subsection{The new industry structure}

The most important change introduced by the LSF is to establish a clean separation between RENFE and the infrastructure manager. The law creates two independent stateowned companies: RENFE-Operator, and the new agency for management of rail infrastructure, ADIF (Administrador de Infraestructuras Ferroviarias). RENFE-Operator is to be established from RENFE's current operating and maintenance business units. But while RENFE-Operator will assume the assets, employees and other liabilities of those business units, most of the outstanding debt will be transferred to the government and taken off the company's balance sheets, a decision that has been criticized by some private companies. As any other rail service provider, RENFE-Operator will be required to obtain a license to operate and will have to pay the access prices set by the infrastructure manager, ADIF.

In theory, the LSF ends RENFE's 60-year monopoly on rail service. The law does not establish particularly tough requirements to new entrants, requiring only proven financial and technical capability. It is obviously early to predict how competition will evolve but experience from similar situations (such as railroads in other countries or the

\footnotetext{
${ }^{11}$ For a more detailed discussion see De Rus and Nombela (2007).

${ }^{12}$ The law was passed in November 2003. However, the new government after the elections of March 2004 decided to postpone it until January 1st, 2005 to study first its consequences.
} 
telecommunications industry in Spain) suggests that the incumbent will still dominate the market power in the initial years. Furthermore, the liberalization of other industries has often included the privatization of the former public monopoly, in order to enhance competition. In the case of the Spanish rail industry, this possibility has been ruled out so far.

ADIF, the new government infrastructure agency, will be responsible for developing and maintaining the traditional network and the high-speed lines, as well as the existing stations and terminals. ADIF will take over GIF's existing infrastructure and personnel and will be also in charge of building new lines, which, for the first time, can be concessioned to private firms in BOT (build-operate-transfer) or other similar regimes. It will report to the Ministry of Development and be financed by a combination of subsidies from the national government, access prices for infrastructure utilization paid by the operators and other surcharges paid by rail customers, such as the so-called "safety tax" of between $€ 0.02$ and $€ 0.30$ per passenger.

\subsection{Infrastructure access prices}

Although GIF had already developed a proposal for infrastructure charging in Spain, the second major change of the 2003 law is to introduce charges for the usage of rail infrastructure, stations and other track elements that conform to EC Directive 2001/14. The new charges, summarized in Table 6, intend to recover ADIF's full costs, and include four components: access, capacity reservation, circulation and traffic. The access charge is a general payment to be made by all licensed operators for the right to use the infrastructure. The capacity reservation and circulation fees depend on the kilometers of track used and vary with the type of service or train, the hour of the day and the characteristics of the track. Finally, the traffic charge is levied on the operators depending on the economic value of their service as measured by the number of seat-kilometers or ton-kilometers operated.

\begin{tabular}{|l|l|l|}
\hline $\begin{array}{l}\text { Charged } \\
\text { item }\end{array}$ & Principles & Economic base for calculation \\
\hline Access & For the right to use the network. & ADIF's administrative costs \\
\hline $\begin{array}{l}\text { Capacity } \\
\text { reservation }\end{array}$ & For the assignment of specific tracks & $\begin{array}{l}\text { ADIF's fixed costs of track } \\
\text { maintenance and operation }\end{array}$ \\
\hline $\begin{array}{l}\text { Circulatio } \\
\mathrm{n}\end{array}$ & For the real use of specific tracks & $\begin{array}{l}\text { ADIF's variable costs of track } \\
\text { maintenance and operation }\end{array}$ \\
\hline Traffic & $\begin{array}{l}\text { For the economic value of the } \\
\text { services }\end{array}$ & $\begin{array}{l}\text { ADIF's financial and } \\
\text { depreciation costs }\end{array}$ \\
\hline $\begin{array}{l}\text { Stations } \\
\text { and yards }\end{array}$ & $\begin{array}{l}\text { For the use of specific stations and } \\
\text { yards }\end{array}$ & Not defined \\
\hline
\end{tabular}

Table 6: Charges for infrastructure use in the new rail law

There are also separate charges for the use of stations and yards, although the law does not explicitly define the procedure for calculating the corresponding prices. It simply states (in article.73.2) that they will be set "in accordance with general principles of economic 
viability, effective exploitation of infrastructure, market conditions, and financial balance, providing non-discriminatory treatment to all licensed operators". ${ }^{13}$

No specific schedule of infrastructure charges have been released so far, so we have yet to see how these principles will be applied in practice. But having a transparent and efficient infrastructure charging regime is a key condition for the successful development of open access in the terms defined by the European rail policy.

\subsection{Rail regulation}

The final major contribution of the LSF is the creation of a Rail Regulation Committee (Comité de Regulación Ferroviaria) to oversee the functioning of the sector and guarantee an equal treatment of all (private and public) operators. The Committee is also charged with resolving disputes that arise between the ADIF and the operators and guaranteeing that access is provided on a non-discriminatory basis.

The Rail Regulation Committee has less independence than similar Spanish regulatory commissions in energy or telecommunications. ${ }^{14}$ Unlike the other commissions, the rail committee is an internal department within the Ministry of Development and five of its six members are directly named by the government. These arrangements do not automatically preclude the committee's independence but they are likely to make suspect any decision that favors the public incumbent over new private competitors. The EU directives are not very clear about what constitutes an independent rail regulatory agency and the new law seems to have taken advantage of this ambiguity.

More recently, the government seems to have realized that further efforts may be needed. In the first quarter of 2005, the government announced a new competition policy which includes, among other proposals, a plan to create a truly independent rail regulation agency outside the Ministry of Development. The plan also calls for some specific disinvestments of RENFE to would-be rivals. As a consequence, at least five small firms have formally announced their interest in entering the market for rail services.

\section{Conclusions}

For the last 60 years, Spain, like the other countries of Europe, has had a single, stateowned railway company, responsible for both infrastructure and track services. However, this protective environment, where competition was rare and often discouraged, was not enough to prevent the decline in the railways' market share and profitability. Indeed, the public monopoly model may have hastened the decline by inhibiting the railway's response to the rapid expansion of more flexible transport alternatives and to traveler and shipper demands for higher quality services. Government policy toward other models contributed as well, particularly the lifting of constraints on competition in the trucking

\footnotetext{
${ }^{13}$ The principles defined in EC Directive 1991/440 are not much clearer. Article 8 states that (the user fee) "... will be calculated in such a way as to avoid any discrimination between railway undertakings, may in particular take into account the mileage, the composition of the train and any specific requirements in terms of such factors as speed, axle load and the degree or period of utilization of infrastructure”. The 1998 White Paper (European Commission, 1998) did not clarify the concept either. For a recent critical discussion, see Rothengatter (2003) and the reply in Nash (2003).

${ }^{14}$ For example, the National Energy Commission (CNE) or the Telecommunication Markets Commission (CMT). For details on its competences, the reader could visit their websites (www.cne.es, www.cmt.es).
} 
industry in 1987, the deregulation of the airline industry since the mid-1980s and the massive highway construction programs of the 1980s and 1990s.

To face all these challenges, RENFE has undergone major reforms in the 1980s and 1990s. The company was gradually transformed into an autonomous commercial body with economic rather than social objectives. It was divided into business units and responsibility for infrastructure management was transferred to a separate government agency. As a result of these changes, RENFE's performance improved greatly in the 19842003 period, but the company remained the sole provider of rail services as the development of regulations to allow the effective introduction of competition was put off for more than a decade.

In recent years, the Spanish government, with the support of the most recent strategies defined by the European rail policy, has opted for a long-term strategy of winning back rail customers through the development of high speed corridors. Following the French model, Spain has devoted considerable resources to an ambitious national high-speed network in order to finally integrate the country regions, reduce congestion and increase personal mobility. Although this risky strategy may prove to be successful, it is also a very expensive one. Besides, high-speed trains sacrifice the rail freight business and its high operating costs will discourage the entry of potential competitors.

In sum, the lack of effective competition has been the most defining characteristic of the traditional rail model in Spain and it is difficult that this will change in the near future. The 2003 Rail Sector Law has established a new framework where RENFE becomes only in operator and the infrastructure manager, ADIF, will demand access charges to all operators. However, the unclear definition of the principles for calculating access prices and the low-profile nature of the new rail regulatory body created within the Ministry of Development suggest that we will have to observe the implementation of the new law with caution before endorse it. The success in the change of the rail model is not guaranteed and the results could be disappointing again.

Therefore, this is a crucial moment for Spain's rail industry. The 2003 law is a big leap forward that could mark the end of an era. But the dream of having the railroad as the "dorsal spine of the country" will hardly become true without sacrifice. Today, the industry faces the challenge of adapting its structure to competition as other infrastructure sectors have already done, or to definitively become and expensive public service, with fast and comfortable trains that would not survive without the caring support of the taxpayers.

\section{$7 \quad$ References}

Campos, J. and P. Cantos (2000) "Railways Regulation", in A. Estache and G. de Rus (ed.), Privatization and Regulation of Transport Infrastructure: Guidelines for Policymakers and Regulators, The World Bank Institute: Washington, DC.

Cantos, P., J.M. Pastor and L. Serrano (1999) "Productivity, Efficiency and Technical Change in the European Railways: A Non-parametric Approach,” Transportation, 26, 4: 337-357

Carbajo, J. and G. de Rus (1991) "Railway Transport Policy in Spain," Journal of Transport Economics and Policy, May: 209-215. 
Comín, F., P. Martín, M. Muñoz, and J. Vidal (1998) “150 Años de Historia de los Ferrocarriles Españoles,” Madrid: Anaya.

De Rus, G. and V. Inglada (1997) "Cost-benefit Analysis of the High-Speed Train in Spain,” Annals of Regional Science, 31: 175-188.

De Rus, G. and G. Nombela (2007) "Is Investment in High Speed Rail Socially Profitable?” Journal of Transport Economics and Policy, 41, 1: 3-23.

Dogson, J. and P. Rodriguez (1996) "La rentabilidad de los diversos servicios de RENFE", in J.A. Herce and G. de Rus (ed.). La Regulación de los Transportes en España, Civitas: Madrid.

European Commission (1998) "Fair Payment for Infrastructure Use: A Phased Approach to a Common Transport Infrastructure Charging Framework in the EU," White Paper, Brussels.

European Commission (2001) "European Transport Policy for 2010: Time to Decide," White Paper, Brussels.

Nash, C.A. (2003) "Marginal Cost and Other Pricing Principles for User Charging in Transport: A Comment,” Transport Policy, 10, 3: 345-348.

Nash, C.A. (2004) "Rail Policy and Planning in Europe," International Journal of Transport Management, 2: 1-3.

Rothengatter, W. (2003) "How Good is First Best Marginal Cost and Other Pricing Principles for User Charging in Transport?” Transport Policy, 10, 2: 121-130. 